MAREK STACHOWSKI

Jagiellonian University in Kraków

stachowski.marek@gmail.com

\title{
A SUPPLEMENTAL NOTE ON THE ORIGIN OF ENGLISH GUINEA PIG
}

Keywords: etymology, English language, Romance languages, biological terminology

\section{Abstract}

This is a note to support a conjecture published some time ago and concerning the mechanism of the emergence of the word guinea as part of the English name of guinea pig.

Some suggestions concerning both English guinea pig and its German equivalent Meerschweinchen are to be found in Stachowski (2014). One of my opinions expressed there was that the name guinea pig is not really connected either with the geographical name of Guinea or with a designation of the ungulate ${ }^{1} p i g$. Another of those opinions was that these two elements should be examined separately, so that the story of the ostensibly original trade price of one guinea for the rodent should certainly be dismissed.

When speaking of the origin of the element guinea, I considered various possibilities and also suggested a somewhat risky solution pivoting around a distortion - imaginable but hard to prove, and thus risky - of a country name surfacing in Romance designations of the guinea pig, like French (cochon) d'Inde, Italian (porcellino) d'India and Portuguese (porquinho-)da-índia id.

The use of the term "ungulate" for pig as opposed to (guinea) pig = (Meer)schweinchen draws on popular imagination rather than on purely biological cladistics. That can easily be understood if one thinks of the re-arrangement of the German term as Meerschwein+chen (in lieu of the popular Meer+Schweinchen; see Stachowski 2014: 223), that is a diminutive form of Meerschwein (= Danish marsvin '1. guinea pig; 2. harbour porpoise' = Polish morświn, English mereswine 'porpoise') because porpoises belong to one of the clads of the ungulates, just as also pigs do. 
I toyed with the possibility of changing the original French d'Inde into an English form ${ }^{\star}$ Dindy which will first have been "simplified" into a ${ }^{\star}$ Dinny and then replaced by the word Guinea, far better known to the English (Stachowski 2014: 225).

Unfortunately, it was not until now that I came across a passage in Ernest Weekley's The romance of words which very well fits my conjecture. ${ }^{2}$ It reads as follows:

Guinea was a vague geographical expression in the $17^{\text {th }}$ century, but not so vague as India or Turkey. Indian ink comes from China (Fr. encre de Chine), and Indian corn from America [...].

No doubt the turkey was confused with other birds, for we find Fr. geline [!, pro: géline] d'Inde before the discovery of America. D'Inde has become dinde [= 'turkey'], whence a new masculine dindon has been formed. (Weekley 1911: 46)

Thus, the possibility of the syntagm $d$ 'Inde becoming an independent word is absolutely real - a fact that makes my conjecture of 2014 fairly workable, even though French dinde means a bird rather than a rodent, and its source d'Inde will possibly have concerned Turkey if the English counterpart of French dinde, namely turkey may be used as an etymological hint.

However, Albert Dauzat says that “l'Inde (occidentale) se rapporte au Mexique, où le dindon fut découvert par les Espagnols", and he adduces the expression coq d'Inde, first attested in 1548, as the oldest known record of the French word (Dauzat 1938: 247). This fact is at odds with Weekley's claim ("before the discovery of America") or the English name turkey. One could say that fact should not concern us too much here because the point of this note is the support of the conjecture of guinea being the result of distortion of the original d'Inde rather than discussing the geographical sense of $15^{\text {th }}$ or $16^{\text {th }}$ century French term Inde.

That is of course true. But, on the other hand, turkey is both similar and related to an African bird of the Galliformes order, namely to guinea-fowl which makes me think that our story of senses and uses of the element guinea in English is not perfectly understood yet.

\section{References}

Dauzat A. 1938. Dictionnaire étymologique de la langue française. Paris.

Stachowski M. 2014. Is the English guinea pig a pig from Guinea, and the German Meerschweinchen a piggy from the sea?, or two old problems revisited. - Studia Linguistica Universitatis Iagellonicae Cracoviensis 131: 221-228.

Weekley E. 1911. The romance of words. New York.

2 I am not going to expatiate on the German term here and will only limit myself to stating that Weekley's formulation “The German name for guinea-pig, meerschweinchen, seems to mean little pig from over the sea" (Weekley 1911: 46) translates the German term in a folketymological way ('from over', for details see Stachowski 2014: 224, 227). 